\title{
Teacher Educators in K-12 Classrooms: How to Nurture Professional Development and Research
}

\author{
Rukiye Didem Taylan \\ MEF University \\ Zelha Tunç-Pekkan* \\ MEF University \\ Utkun Aydın \\ American University of the Middle East \\ Bengi Birgili \\ MEF University
}

Four mathematics teacher educators taught $5^{\text {th }}$ grade mathematics for one year at a disadvantaged public school in a metropolitan city in Turkey. Teacher educators (TE) met every week for 10 months where they discussed what to teach, how to teach and reflected on implementation of their shared planning (Regular Meetings). In some meetings, there was a special focus on teaching and learning of fractions (Fraction Research Meetings). Videotapes of the first six Regular Meetings and six of the Fraction Research Meetings were analyzed. The focus of qualitative analyses was on how the pedagogical content knowledge (PCK) was constructed during meetings. References evidencing TEs' knowledge of students, instructional strategies and assessment were revealed more frequently during the Fraction Research Meetings compared to the Regular Meetings. Findings showed that TEs were more focused on what questions to ask in the classroom and shared their experiences about students' mathematical thinking more frequently. Framing planning and reflection discussions with a focus on conducting research was a productive way of nurturing professional development for TEs.

Keywords: mathematics, pedagogical content knowledge, professional development, teacher educators, teaching experience

\section{INTRODUCTION}

What teachers should know in order to teach mathematics effectively has been a topic of debate for some time in the field of teacher education. Today there is a wide agreement that teachers should have knowledge and practices related to pedagogical content knowledge (PCK) (Shulman, 1986), i.e. both content knowledge and how it is taught (Torbeyns, Verbruggen, \& Depaepe, 2020). Accordingly, recent 
recommendations for beginning teachers (König \& Rothland, 2012; Wilhelm, 2014) state that teachers should know how students learn a particular topic and develop PCK specific to teach mathematics.

PCK is introduced by Shulman (1986) as: "special amalgam of content and pedagogy that is uniquely the province of teachers, their own form of professional understanding" (p.227). According to Shulman, PCK contained the most effective examples and explanations to teach a particular topic. In this vein, in a study on mathematics teachers' PCK, Lannin et al. (2013) conceptualized PCK to include: Knowledge of student understandings within mathematics (KSUM), Knowledge of instructional strategies for mathematics (KISM), Knowledge of curriculum for mathematics (KCM), and Knowledge of assessment for mathematics (KAM). In this adaptation of PCK, researchers viewed "PCK as knowledge for mathematics teaching that may or may not involve strong connections to the actual teaching and learning of mathematics" (Lannin et al. 2013; p. 406). In this study we framed PCK according to this recent perspective, where personal justifications or beliefs of teacher educators in this study are also considered as part of their PCK.

Teacher educators can be defined as the higher education academic staff with a responsibility for teacher education, research or subject studies and didactics, who are in charge of teachers' continuous professional development (Dengerink, Lunenberg, \& Kools, 2015). In this accordance, being a teacher educator may involve different roles and responsibilities depending on the context associated with different professional identities (Ping, Schellings, \& Beijaard, 2018). In a review of articles on professional development of teacher educators, Swennen, Jones and Volman (2010) reported that previous research studied teacher educator identities in the form of: (former) school teacher; as a teacher in higher education; as a teacher of teachers; and a sub-identity as a researcher. Modeling values and skills associated with teaching for pre-service teachers was considered one of the key elements that distinguished teacher educators from being school teachers.

Although teacher educators are considered to have lasting influence on the nature of both teacher and student learning (Cochran-Smith, 2003), required knowledge and skills in order to provide support for preservice teachers and student learning remains elusive (Ping et al., 2018). Similarly, although development of teachers' PCK has been relatively well explored (Depaepe, Verschaffel, \& Kelchtermans, 2013), research on the development of PCK of teacher educators is scarce.

\section{PCK for Teacher Educators}

Pedagogical Content Knowledge (PCK) framework (Shulman, 1986) has long been used as a tool to study teacher knowledge and development in the field of teacher education (Abell, 2007; Aydın \& Boz, 2012; Deapepe et al., 2013). PCK was used to investigate different aspects of teacher knowledge and skills, and was found helpful in illustrating teacher knowledge at different levels of a professional continuum. Previous studies on PCK mostly involved pre-service teachers (Aydın \& Boz, 2012; Bukova-Guzel, 2010; Turnuklu \& Yesildere, 2007) and in-service teachers (Henze, van Driel, \& Verloop, 2008; Wilson, 2008). Although there is agreement that PCK for teachers has a potential to serve in understanding PCK for teacher educators in general (Abell, Rogers, Hanuscin, Lee, \& Gagnon, 2009), and for mathematics teacher educators, in particular (Chauvot, 2009), studies that specifically focused on teacher educators' PCK development included a sample of science teacher educators (e.g., Abell et al. 2009; Demirdöğen, Aydın, \& Tarkın, 2015) and few studies involved a sample of mathematics teacher educators (Chick \& Beswick, 2018). It is also important to note that these studies considered teacher educators' PCK for teaching teachers. In our study, however, we consider teacher educators' PCK in the role of teachers who also conducted research at a K-12 school.

Self-studies by teacher educators (Zeichner, 1999) helped illuminate nature and sources of knowledge needed to become a teacher educator and ways to enhance teacher educator knowledge and practices (Chauvot, 2009; Loughran, Mulhall, \& Berry, 2008). For instance, Chauvot's (2009) self-study revealed that subject matter knowledge, PCK and knowledge of context were necessary in her practices. In general, however, studies on teacher educators did not focus on PCK but rather listed qualities of professional knowledge in order to become teacher educators (Moradkhani, Akbari, Ghafar, \& Kiany, 2013). 
Although teachers and teacher educators are assumed to share similar responsibilities, there are also important differences in their work (Smith, 2005), which call for further investigation regarding the nature of teacher educator's PCK. A study by Smith (2005) revealed that some of the many aspects of teacher educators' knowledge that differed from teachers' knowledge included making connections between theory and practice and conducting research, which was considered as professional development. Teaching, on the other hand, was not as theoretical. In many countries, teaching experience and advanced degrees are required standards to become teacher educators (Korthagen, 2000). However, beyond these qualities, there is a need to understand what kind of professional development experiences for teacher educators are needed so that they can develop their expertise in better ways (Abell et al., 2009; Smith, 2005).

\section{Professional Development of Teacher Educators}

In their review on teacher educators' professional learning, Ping et al. (2018) suggested that there was a need for establishing a knowledge base required for being a teacher educator. The main professional development activities that teacher educators engaged in included learning through academic engagement, collaborative activity, attending professional development programs and engaging in reflective activity (Schön, 1983). Academic engagement in general referred to activities such as conducting research projects and attending to conferences. Conducting research involved self-study of teacher education practices or investigations in order to contribute to theoretical knowledge in teacher and student learning. The authors proposed that content of professional development for teacher educators should focus on "pedagogy of teacher education, research and reflection, professional identity and different kinds of knowledge" (Ping et. al., 2018; p. 104). Self-studies of researchers as teachers were not mentioned by the authors. Such studies may allow researchers investigate research problems directly related to teaching and learning that is faced every day at schools and thus bridge the gap between university and K-12 schools. Such experiences hold the potential to allow teacher educators advance in both PCK and conducting research.

In an explorative international study, van der Klink, Kools, Avissar, White, and Takata (2017) underlined that daily activities of being a teacher educator served as sources of professional development, such as attending to meetings and engaging in discussions with colleagues. Participating in communities of practices (Lave \& Wenger, 1991) and collaborative activity was considered important for teacher educators' growth (Hadar \& Brody, 2010). Helping teacher educators enhance their professional knowledge and experiences involved creating opportunities of interaction with students as well as conducting research and taking a reflective stance on one's own work (Byrd et al., 2011; Chauvot, 2009; Loughran, Mulhall, \& Berry, 2008).

Indeed, professional learning activities of teacher educators could be categorized as the following: learning through academic engagement, learning through collaborative activity, learning through attending professional development programs, and learning from reflective activity and research (MacPhail et al., 2019; Ping et al., 2018). Collaborative activity was considered important for teacher educators' growth. In some studies teacher educators learned from each other in order to realize a common goal (Hadar \& Brody, 2010) or learned by exchanging professional ideas with school teachers and teacher candidates (Sharplin, 2011).

Teacher educators' perceptions related to professional learning seem to be influenced by culture and requirements of being a teacher educator in a specific context (Ping, Schellings, Beijaard, \& Ye, 2020). In some countries such as the UK, Netherlands, the United States and Finland, teacher educators are required to have K-12 teaching experience before they become teacher educators in a university (Jenset, Klette, \& Hammerness, 2018; Murray, Swennen, \& Shagrir, 2009). Selecting teacher educators who are able to connect clinical experiences with teacher education courses is considered important (Forzani, 2014). In contrast, majority of teacher educators in Turkey do not have K-12 teaching experience. University teacher education and teaching in schools are viewed as disconnected (Çakıroğlu \& Çakıroğlu, 2009; Kasapoğlu, 2015). In this context, there is a need to know how teacher educators themselves construct PCK, which would help them design better learning experiences for pre-service teachers. Considering the cases of teacher education from countries of the United States and Finland, Forzani (2014) implied that there has been variety of efforts to select teacher educators who are able to link the teaching practices and the theory 
behind the teaching and learning. To be a teacher educator, a key concern is to connect clinical experiences more firmly to courses so that teacher education is not only theoretical. In Finland, teacher educators are encouraged to train new teachers through university-school partnerships, there is a focus upon new teachers' learning such as teacher training schools which is mostly focused on practice (Niemi, 2016; Niemi \& JakkuSihvonen, 2006). Namely, teachers' pedagogical studies include teaching practice, which is completed at teacher training schools run by universities and at affiliated schools. As seen in Finland example, practicebased teacher education is getting widely recognized which means teacher educators may need to expand their knowledge base in order to become more competent teacher educators.

Self-study of teacher educators is regarded as systematic research and reflection on one's own practices, which may renew and reform those practices and contribute to knowledge base of teacher educators (Zeichner, 1999). This in turn supports teacher educators' self-confidence as researchers and teaching teachers, which involves modelling of teaching activities and values for pre-service teachers (Lunenberg, Korthhagen \& Zwart, 2011). A study by Lunenberg et al. (2011) brought self-study experiences of teacher educators on the scene indicating that these experiences supported teacher educators' growth by allowing them to produce knowledge related to their own practice, which also led to growth in self-confidence. Furthermore, self-study has been found to be an important way to support teacher educators' professional identities in not only as researchers but also as teaching teachers which involves modeling of teaching activities and values for pre-service teachers (Lunenberg \& Hamilton, 2008; Lunenberg et al. 2011).

\section{A Self-Study in the Context of the University Within School Model}

Several studies have shown that teacher education is a process of learning to understand and act in the school context in general, and in the classroom environment in particular (e.g., Darling-Hammond, 2006; Loughran, 2006). Researchers (Jones \& Ryan, 2014; Özcan, 2013) emphasized that for this process to be productive there needs to be rich communication among universities and schools. Many have claimed that universities and schools should form partnerships that create a space for relationship building and conversation (Kruger, Davies, Eckersley, Newell, \& Cherednichenko, 2009). Among those who recommend such collaborative partnerships is Darling-Hammond (2006), pointing the need for a harmony with shared aims, committed resources and effective communication between schools and universities. In other words, a mutually supportive alliance including the triangle of (1) in-service teachers, (2) pre-service teachers, and (3) teacher educators is necessary (Özcan, 2013). In this tripartite relationship, teacher educators can also benefit through the opportunities that partnerships provide to bridge the theory-practice gap (e.g., Smedley, 2001), build links within and among school-based faculty knowledge and experience (e.g., Molseed, 2000), and keep up-to-date with school issues and curriculum (e.g., Bartholomew \& Sandholts, 2009). In relation to these benefits, teacher educators in universities, who are given the chance to get K-12 teaching experience (Sharplin, 2011) often report their benefits of working with schools and feel they are contributing to the profession by engaging in the professional development. In such conditions teacher educators are most likely to develop their PCK as teachers.

Although there are many positive impacts identified for partnerships that explored teacher professional development (e.g., Sandholtz, 2002), university-school partnerships that focus on the professional development of teacher educators are still rare (e.g., Cochran-Smith, 2003; Jones \& Ryan, 2014). The professional development of teacher educators is studied and presented in the relevant literature in many different ways (e.g., transforming their theory-based knowledge into practice for the benefit of their own growth). But at the core of such endeavors is usually the understanding that professional development is about teachers' (i.e., in-service teachers) and teacher educators' (i.e., researchers) collaboration in analyzing and improving for instance teaching in general (e.g., Yogev \& Yogev, 2006), and mathematics teaching in particular (e.g., Krainer, 2008; Potari, Sakonidis, Chatzigoula, \& Manaridis, 2010).

Viewed together, university-school partnerships hold significant potential to enhance teacher educators' professional development and thereby foster pre-service teacher learning. Consequently, partnerships are a prevalent element of teacher education research efforts, and thus we believe that if teacher educators integrate theory and practice, as is the case in the present research, the PCK that they gain through K-12 teaching experience can be improved more effectively when incorporated with the research-based 
experiences. The present study is part of a larger project in the context of the University within School model (Özcan, 2013) in Turkey. This model was initiated by a Faculty of Education, which aimed to improve teacher education and student learning by closing the gap between teacher education practices and school experience in Turkey. The model requires that as part of professional development, teacher educators should regularly renew their teaching experiences in K-12 schools. In the context of this project, teacher educators acted as 5th grade mathematics teachers in a public school. This one-year long experience positively impacted students' mathematics achievement in an otherwise disadvantaged school located in a low-level socio-economic neighbourhood (Aydın et al., 2017).

The purpose of this self-study is to explore teacher educators' PCK development during this experience. More specifically, the study investigated qualitative differences in teacher educators' PCK development during when they both taught and conducted research on a specific topic (fractions) versus when they only engaged in teaching without a specific research agenda. From a pedagogical point of view using self-study experiences can effectively inform teaching and teacher education. Mathematics educators improving their knowledge related to students, curriculum, instructional strategies and assessment can portray their professional learning experience while conducting research in an authentic context. In this sense, the project in the present study offers relations specific for mathematics educators as well as holds parallels and provides directions that may account for other teacher educators in other disciplines.

\section{METHOD}

The research team investigated their own professional development, how teacher educators as teachers constructed different domains of PCK by adopting Lannin et al. (2013)'s conceptualization as they planned and debriefed mathematics lessons. In this study, self-study (Zeichner, 1999) and a qualitative design was followed (Patton, 2002). Using self-study techniques provides teacher educators with the opportunity to comprehend their experiences - namely teacher educators acting as teachers and conducting research - in more profound ways as opposed to others (Lunenberg et al., 2011).

\section{Participants}

Four female teacher educators, whose ages ranged from 27 to 38 years, participated in the present study. Three of them were full-time faculty members and one of them was a research assistant in Middle School Mathematics Teaching Department at a private university. At the time the study was conducted Teacher Educator 1 (first author) had student teaching experience for one year and experience in conducting schoolbased research; Teacher Educator 2 (second author) had one year of full-time high school mathematics teaching experience besides 14 years of teaching at the college and graduate level. Her research mainly focused on children's construction of fractions. Teacher Educator 3 (third author) had 12 years-experience of teaching at the undergraduate and graduate levels and one-year experience of private tutoring; Teacher Educator 4 (fourth author) had one-year experience of curriculum development practice and research as well as assessment. While teacher educators had different teaching experiences previously, teaching 5th grade mathematics was a novel experience for all of them.

\section{Context of the Study}

As a group, teacher educators attended planning and reflection meetings every week during one academic year at the university and taught 5 th grade mathematics at the partnership school located in a low socioeconomic neighborhood. There were 40 meetings in total. In each meeting, the group discussed how to plan lessons for 5th grade mathematics and reflected on the previous lessons. When teaching fractions, the research team designed fraction lesson plans using Fraction Scheme Theory (Steffe \& Olive, 2010). This theory was based on teaching experiments conducted for a long period with students by various researchers (Tunç-Pekkan, 2008; Tunç-Pekkan, 2015; Norton \& Wilkins, 2012, Tzur, 1999). According to this theory, students construct fractional schemes through reorganization of whole-number schemes. More specifically, students use their whole number knowledge and modify it for constructing knowledge on fractions (Steffe \& Olive, 2010). In this regard, fraction tasks were introduced and students' problem- 
solving strategies were monitored. Details on authors' teaching and student learning based on this theory can be found elsewhere (Aydin et al., 2018).

\section{Data Sources and Data Collection}

The data sources were the transcriptions of video-recorded meetings (recorded by teacher educators), and classroom instructions in the practice school. It is important to differentiate two types of meetings: Regular Meetings (RM) $(n=6)$ and Fraction Research Meetings (FRM) $(n=6)$. For this study, the researchers analysed the first 6 RM which took place in the Fall semester and the first 6 of the FRM which took place in the Spring semester. During the RM, lesson plans were developed based on the mathematics textbook by Ministry of Education. In contrast, during the FRM, the teacher educators designed and reflected on the implementation of lesson plans based on the Fraction Scheme Theory (Steffe \& Olive, 2010). Furthermore, during the FRM, videotapes of classroom instruction were discussed and certain noticing and instructional moves (examples, explanations, questions, etc.) were shared with reference to the experiences of each teacher educator. Although the classroom instruction videos were discussed in the meetings as additional data sources, they were not the main focus of data analysis. Each meeting took around 2 hours and transcribed verbatim. All necessary ethical guidelines were fulfilled for this study.

\section{Data Analysis}

In order to analyse the meeting transcriptions and determine the teacher educators' development in their PCK during the meetings, PCK Framework (Lannin et al., 2013) was used (Table 1). This framework includes four components: KCM, KAM, KISM and KSUM. Content analysis (Stemler, 2001), was utilized to analyze the transcriptions of group meetings. The unit of analysis (Yin, 1994) was determined to be a meaningful teaching move. Then each thought, explanation or discussion related to a teaching move was labeled as associated with one or more components of the PCK framework (see Table 2 for examples related to each component). Finally, we calculated frequencies of each knowledge domain that emerged in each meeting. Total frequencies for the RM and the FRM were calculated respectively (see Table 3) which revealed nature of PCK evidenced in teacher educators as a team.

TABLE 1

\section{PCK COMPONENTS AND CODES (LANNIN ET AL., 2013)}

\begin{tabular}{ll}
\hline PCK Component & PCK Codes \\
\hline Knowledge of instructional strategies for & How to organize instruction \\
mathematics (KISM) & Specific actions that the teacher can take during \\
& instruction \\
& Activities to use for specific mathematical content \\
& What materials are needed for instruction \\
& What representations are best for particular content \\
\hline Knowledge of student understandings & Student misconceptions \\
within mathematics (KSUM) & Student difficulties \\
& When students find certain concepts easy to understand \\
& How students might approach a concept or problem \\
& What strategies a student may use to solve a problem \\
& Student prior knowledge \\
\hline Knowledge of curriculum for & Goals for instruction \\
mathematics (KCM) & Curricular resources \\
& Content of textbooks (i.e., specific knowledge of things \\
included in curricular materials) \\
Scope and sequencing of mathematical topics \\
National, state, and/or local standards \\
\hline
\end{tabular}




\begin{tabular}{ll}
\hline Knowledge of assessment for & Why they assess students \\
mathematics (KAM) & How they assess students \\
What they do with the information gathered from \\
assessment \\
Assessment challenges \\
Strategies for assessment \\
Potential teacher responses based on assessment results \\
Purposes of assessment \\
What to assess \\
\hline
\end{tabular}

TABLE 2

PCK COMPONENT EXAMPLES IN RM AND FRM

\begin{tabular}{|c|c|c|}
\hline $\begin{array}{l}\text { PCK Components } \\
\text { (Individual or Multiple) }\end{array}$ & Examples of Coding Excerpts & $\begin{array}{l}\text { Teacher Educators' } \\
\text { Comments }\end{array}$ \\
\hline $\begin{array}{l}\text { A. Knowledge of student } \\
\text { understandings } \\
\text { within mathematics } \\
\text { (KSUM) }\end{array}$ & $\begin{array}{l}\text { TE 3: In this video, let's look, Cenk said (by } \\
\text { showing Cuisenaire Rods) "White is the } \\
\text { biggest because there are more pieces." We } \\
\text { need to talk about it and discuss. This shows } \\
\text { that these students do not demonstrate } \\
\text { understanding of the meaning of fractional } \\
\text { units. } \\
\text { TE4: This happened in my class, as well. } \\
\text { FRM Week } 3\end{array}$ & $\begin{array}{l}\text { Discussion of these } \\
\text { examples add to teacher } \\
\text { educators' knowledge } \\
\text { of students' } \\
\text { understanding of } \\
\text { fractions. This excerpt } \\
\text { was coded as KSUM. } \\
\text { In this example the } \\
\text { teacher educator } \\
\text { mentions a student's } \\
\text { misconception from her } \\
\text { class [white cubes are } \\
\text { the smallest cubes } \\
\text { mathematically]. }\end{array}$ \\
\hline $\begin{array}{l}\text { B. Knowledge of } \\
\text { instructional strategies for } \\
\text { mathematics (KISM) }\end{array}$ & $\begin{array}{l}\text { TE 1: In solving this example, I think we have } \\
\text { to discuss the difference between estimation } \\
\text { and rounding. } \\
\text { TE 2: I agree with you but even in the topic of } \\
\text { estimation and rounding, we should begin the } \\
\text { lesson with daily-life examples. We should } \\
\text { also tell students how to use these } \\
\text { mathematical expressions in daily life. }\end{array}$ & $\begin{array}{l}\text { This shows that the } \\
\text { teacher educators } \\
\text { aimed to use daily-life } \\
\text { examples as an } \\
\text { instructional strategy in } \\
\text { order to make the } \\
\text { lesson more meaningful } \\
\text { for students. }\end{array}$ \\
\hline & RM Week 2 & \\
\hline
\end{tabular}




\begin{tabular}{|c|c|c|}
\hline $\begin{array}{l}\text { C. Knowledge of } \\
\text { assessment for mathematics } \\
\text { (KAM) }\end{array}$ & $\begin{array}{l}\text { TE 3: In order to assess student thinking I } \\
\text { asked: } \\
\text {-How many of red rods are equivalent to the } \\
\text { brown rod? [by showing the Cuisenaire Rods] } \\
\text { - The answers " } 4 \text { " came from the class. } \\
\text {-"Why is it so?" I asked in order to deepen the } \\
\text { discussion. } \\
\text { - What is the logic behind? } \\
\text {-Student: Because when you put } 4 \text {, it becomes } \\
\text { whole, } 1 / 4,2 / 4,3 / 4,4 / 4 \text {. [the student gives } \\
\text { correct answer that } 4 \text { red rods equal to a } \\
\text { brown rod] } \\
\text { FRM Week } 3\end{array}$ & $\begin{array}{l}\text { This shows how the } \\
\text { teacher educators used } \\
\text { assessment in class by } \\
\text { questioning. }\end{array}$ \\
\hline $\begin{array}{l}\text { D. Knowledge of } \\
\text { curriculum for mathematics } \\
(\mathrm{KCM})\end{array}$ & $\begin{array}{l}\text { TE 1: Why were the topic of patterns added to } \\
\text { that page in the math book? [KCM] } \\
\text { TE 3: It's about finding the patterns rule. } \\
\text { TE 2: Should we give the patterns after we } \\
\text { explained the natural numbers? } \\
\text { RM Week } 2\end{array}$ & $\begin{array}{l}\text { This shows that the } \\
\text { teacher educators } \\
\text { inquire the sequence of } \\
\text { concepts when relying } \\
\text { on national curriculum. } \\
\text { This is related to } \\
\text { constructing knowledge } \\
\text { of curriculum, } \\
\text { specifically sequencing } \\
\text { of mathematical topics. }\end{array}$ \\
\hline
\end{tabular}

\section{Trustworthiness}

Data analysis procedures were conducted such that they were reliable and valid. Trustworthiness of the study was ensured through certain steps. First, all transcriptions were analyzed by two of the researchers in different time intervals. To test the trustworthiness of the content analysis, inter-rater reliability was calculated as $87 \%$, which was appropriate (Krippendorf, 2004). Finally, all members of the research team were accessed for a discussion on the findings of the study, which provided member check.

\section{RESULTS}

Results of the data analysis indicated several different patterns with regards to PCK development in two types of meetings. The analyses revealed that frequencies of coding related to components of PCK: KSUM, KISM, and KAM appeared to increase in number for the FRM compared to the RM. On the other hand, frequency of the coding of KCM decreased in the FRM compared to the RM (as seen in Table 3).

TABLE 3

TOTAL FREQUENCIES OF PCK COMPONENTS EMERGED IN THE RM AND THE FRM

\begin{tabular}{lllll}
\hline & $\begin{array}{l}\text { A. Knowledge } \\
\text { of student } \\
\text { understanding }\end{array}$ & $\begin{array}{l}\text { B. Knowledge of } \\
\text { instructional } \\
\text { strategies }\end{array}$ & $\begin{array}{l}\text { C. Knowledge of } \\
\text { assessment }\end{array}$ & $\begin{array}{l}\text { D. Knowledge of } \\
\text { curriculum }\end{array}$ \\
\hline 6-RM & 20 & 21 & 18 & 17 \\
\hline 6-FRM & 24 & 28 & 22 & 9 \\
\hline
\end{tabular}


Typical examples of coding for both the RM and the FRM are provided below (examples of coding associated with different PCK domains are italicized). Some moves were coded under two or even three categories of PCK. The analyses suggested several PCK dimensions were evidenced together in some cases.

During one of the FRM (09.03.2015) the teacher educators reflected on how they could introduce the concept of "unit fractions" in their classes using Cuisenaire rods as manipulatives (KISM). TE 3 shared her experience: "using Cuisenaire rods, I asked the class: 'what could we name the brown rod if the purple rod is 1?" Her goal was to help students use the concept of "unit" in answering this question. She reported that her students came to use of "multiple" for comparing small rods to the larger rods (KSUM). Based on this shared experience, the group members suggested they could introduce unit fractions by reversing the comparison; starting with a larger rod and assigning it as " 1 " and posing the question: "what name would you call the smaller rod?" (KISM). In this example, we observe that teacher educators discuss how to ask better questions based on their shared experiences. This excerpt, which is shortened here, resulted in coding as KISM, KSUM, and KCM. It is important to note that we do not necessarily make claims about quality of the PCK but that we identify when a dimension of the PCK emerges in the meetings as teacher educators plan and reflect on their practices.

During the RM, teacher educators discussed the order of the topics and examples in the official curriculum. For example, on 18.09.2015, TE 4 discussed teaching patterns by using the examples in the book. She shared how students in her class were not able to make a transition from drawing figures to thinking mathematically in a given situation (KSUM). In response to this comment, TE 2 asked "what is the purpose of teaching these patterns to $5^{\text {th }}$ graders?" (related to KCM). This discussion did not lead new examples or goals for the lesson. Teacher educators were hesitant to change what and how to teach. Therefore, new KCM or KISM were not as likely to be constructed as during the FRM when teacher educators engaged in collaborative planning. This moment was one of the several examples comparing how discussions in the RM did not appear to be as productive with regards to building instruction on students' thinking.

Considering reflections of teacher educators in the last meetings, conducting research along with planning seemed to help engage both students and teacher educators themselves. As an illustration, see excerpt 1 from the last FRM:

TE 2: Having lesson plans about fractions enabled us to focus more on the subject. Student thinking took a more important role in the meetings...We started to consider more of: What did the students say or do?

TE 1: Exactly. How can we ask better questions? ... What can we change in the program based on what we observe in student thinking?

TE 2: We use visuals more frequently [in fractions plans compared to others]. We make connections, we use the theory: how does the student learn? There is a lot of modelling, we use the Cuisenaire rods [manipulatives]. Fraction planning is considerably different.

TE 2: It is great to watch our lessons and talk about it for 15-20 minutes.

We were doing the example given in the book [compulsory book of Ministry of Education] previously. But why did the book give that example? We are more conscious of selecting such examples in our own planning.

The results of the data analysis revealed that the frequencies of coding corroborated with expected categories. The KISM emerged more during the FRM compared to the RM as teacher educators tried to figure out which strategies to use during the implementation of research unit (see Table 3). In the FRM, the research team intended to assess student thinking, understand student thinking, and build instruction using student thinking. Therefore, in line with increase in the coding KISM, it could be expected that KSUM and KAM codes also increased during the FRM. Perhaps, because teacher educators did not have a textbook to rely on for fractions, coding for KCM decreased in the FRM. In summary, as seen in excerpt 1, teacher educators reported that they were motivated to observe and assess student understanding as a result of using different instructional strategies and materials (i.e. Cuisenaire rods). 


\section{DISCUSSION AND IMPLICATIONS}

Overall, findings indicated during both types of meetings TEs appeared to construct different domains of PCK. Comparing FRM and RM, the frequencies of related PCK codes (KISM, KSUM, KAM) were higher for the FRM. Only one code, KCM was higher for the RM compared to FRM, which could be related to the fact that teacher educators planned using a textbook in the RM. The FRM where the focus of discussions was on building instruction based on a theory and students' thinking appeared to provide opportunities for teacher educators to improve their PCK in different domains (see Table 3). There may be several different reasons as to why teacher educators reflected that conducting research enhanced their professional growth in better ways compared to teaching with no specific research agenda (Table 3 and excerpt 1). This could be linked to previous research (Swennen et al., 2010) in the sense that the teacher educators thought conducting research was also in line with their sub identity of researcher in addition to being a teacher. Additionally, use of videos in the FRM may also offer an explanation as to why frequency of some PCK codes were higher in FRM compared to RM. During the FRM, the research team discussed videotapes of their instruction as a team. PCK construction likely were improved by video viewing and reflections as well as teaching experience as mentioned by previous research (Ping et al., 2018). Video viewing may have also enhanced teacher educators' noticing of student thinking which could be connected to their PCK (Sherin, Jacobs \& Philipp, 2011). Future research is needed to investigate influence of video viewing on the development of PCK separately.

The findings were in line with previous research that conducting research together in a school setting may be beneficial in constructing PCK for teacher educators, and contribute to professional development of teacher educators (van der Klink et al., 2017). The contribution of this study on PCK development of teacher educators is novel in the sense that teacher educators were not in collaboration with school teachers but they assumed the role of being mathematics teachers for one year. Previous research tended to focus on examples of collaboration of practicing teachers with teacher educators. It is important to differentiate these types of research in their contribution to teacher education and practices. Both approaches-collaborating with teachers in research and collaborating as teacher educators only may offer different perspectives. For instance, working with teachers may require managing power dynamics between teacher educators and teachers (Sharplin, 2011). Innovative or research-based instructional strategies may instigate resistance in some teachers. From this perspective, working as teacher educators as a group may have allowed the group to be more productive in implementing research-based strategies. On the other hand, having a practicing teacher in the group could be beneficial in developing plans more appropriate for this group of students and allow for a better partnership between school and the university. This merits further research about teacher and teacher educator learning who engage in similar professional development practices in different types of groups and contexts. This may allow the teacher education field to understand more about productive types of teaching and research for both teacher and teacher educator PCK development. While the focus of this paper was not student learning, other research studies may compare student learning in different research designs. Accumulation of similar studies may help the field gain insights about which types of studies may be more productive for teacher, teacher educator and student learning.

Similar to previous research, engaging in reflective activity in a collaborative manner and planning lessons as a group was found helpful for the professional learning of teacher educators. Our study extends previous research by providing a comparison of different types of experiences. When teacher educators engaged in conducting research on the learning of fractions, they appeared to have more opportunities for professional growth compared to engaging in teaching experience alone. There is a need for studies which document how teacher educators can make the most of similar professional learning opportunities. In this paper we focused on teacher educators. From a broader perspective, this type of research conducted in actual schools by teacher educators can help the field close the gap between schools and universities. Additionally, research conducted in this setting may prove more realistic and beneficial to teachers and students as the research is conducted in mathematics classrooms. In this context, teacher educators involved in research were actually engaged in teaching who were able to observe influence of their teaching on student learning themselves and had a chance to revise their practices. Owning responsibility on their own 
professional learning as teacher educators without interference of facilitators may also have contributed to teacher educators' positive views about the experience (Vanassche, \& Kelchtermans, 2016). Future studies may investigate whether including facilitators in similar practices could be helpful for teacher educators' learning.

One limitation of this study is that only a subset of the transcriptions was used for data analysis (6 RM and 6 FRM). In total, there were 6 FRM and 34 RM. Our assumption was that equal number from each type of meetings may allow for better comparison of development of PCK. This decision in data analysis allowed us to compare frequencies related to the construction of PCK during different meetings. Another limitation is that we did not pay specific attention to the quality of PCK but that there was evidence of construction of it. Future studies may evaluate units of PCK and not only count their evidence.

Overall, we conclude that engaging in this research provided opportunities for teacher educators to become reflective and construct PCK. Other research (Aydin et al., 2018) indicated that students learning fractions in this model scored better compared to public school students receiving regular instruction. From both perspectives, this partnership between university and school seem to be productive. Future research may also investigate how teacher educator professional development experiences such as this one may transfer to their teacher education course practices. This would provide an opportunity to see influence of teacher educator learning on their teaching at the university teacher education courses and supporting teacher candidates.

To our knowledge, this type of research is not common in teacher education. The results suggest that there is a need for similar studies in teaching mathematics or other subjects in different contexts. Based on this experience, conducting research while teaching at K-12 is strongly recommended and may be considered a robust way of professional development for teacher educators. In turn, this type of professional development could help teacher educators become better models for pre-service teachers as well as contribute to research in both student and teacher learning. It is our hope that other teacher educators can be equipped with resources to engage in similar experiences in the future.

\section{ACKNOWLEDGEMENTS}

The research reported in this paper was supported by Turkish Science Academy Young Scientist Award Program; and MEF University, Research Projects Support Program.

\section{REFERENCES}

Abell, S.K. (2007). Research on science teacher knowledge. In S.K. Abell \& N.G. Lederman (Eds.), Handbook of research on science education (pp. 1105-1149). Mahwah: Lawrence Erlbaum.

Abell, S.K., Rogers, M.A.P., Hanuscin, D.L., Lee, M.H., \& Gagnon, M.J. (2009). Preparing the next generation of science teacher educators: A model for developing PCK for teaching science teachers. Journal of Science Teacher Education, 20(1), 77-93.

Aydın, S., \& Boz, Y. (2012). Review of studies related to pedagogical content knowledge in the context of science teacher education: Turkish case. Educational Sciences: Theory \& Practice, 12(1), 497505.

Aydın, U., Tunç-Pekkan, Z., Taylan D., Birgili, B., \& Özcan, M. (2018). Impacts of a university-school partnership on middle school students' fractional knowledge: A quasiexperimental study. The Journal of Educational Research, 111(2), 151-162. DOI: 10.1080/00220671.2016.1220358

Aydın, U., Tunç-Pekkan, Z., Taylan, R.D., \& Birgili, B. (2017). Equity in middle school students' fractional knowledge: Does school type matter in Turkey? European Journal of Education Studies, 3(9), 480-496.

Bartholomew, S., \& Sandholtz, J. (2009). Competing views of teaching in a school-university partnership. Teaching and Teacher Education, 25(1), 155-165.

Bukova-Guzel, E. (2010). An investigation of pre-service mathematics teachers' pedagogical content knowledge, using solid objects. Scientific Research and Essays, 5(14), 1872-1880. 
Byrd, D.R., Hlas, A.C., Watzke, J., \& Valencia, M.F.M. (2011). An Examination of Culture Knowledge: A Study of L2 Teachers' and Teacher Educators' Beliefs and Practices. Foreign Language Annals, 44(1), 4-39.

Çakıroğlu, E., \& Çakıroğlu, J. (2003). Reflections on teacher education in Turkey. European Journal of Teacher Education, 26(2), 253-264.

Chauvot, J.B. (2009). Grounding practice in scholarship, grounding scholarship in practice: Knowledge of a mathematics teacher educator-researcher. Teaching and Teacher Education, 25(2), 357-370.

Chick, H., \& Beswick, K. (2018). Teaching teachers to teach Boris: A framework for mathematics teacher educator pedagogical content knowledge. Journal of Mathematics Teacher Education, 21, 475499.

Cochran-Smith, M. (2003). Learning and unlearning: The education of teacher educators. Teaching and Teacher Education, 19(1), 5-28.

Darling-Hammond, L. (2006). Constructing 21st century teacher education. Journal of Teacher Education, 57(3), 300-314.

Demirdöğen, B., Aydın, S., \& Tarkın, A. (2015). Looking at the mirror: A self-study of science teacher educators' PCK for teaching teachers. Eurasia Journal of Mathematics, Science and Technology Education, 11, 189-205.

Dengerink, J., Lunenberg, M., \& Kools, Q. (2015). What and how teacher educators prefer to learn. Journal of Education for Teaching, 41(1), 78-96.

Depaepe, F., Verschaffel, L., \& Kelchtermans, G. (2013). Pedagogical content knowledge: A systematic review of the way in which the concept has pervaded mathematics educational research. Teaching and Teacher Education, 34(1), 12-25.

Forzani, F.M. (2014). Understanding "core practices" and "practice-based" teacher education: Learning from the past. Journal of Teacher Education, 65(4), 357-368.

Hadar, L., \& Brody, D. (2010). From isolation to symphonic harmony: Building a professional development community among teacher educators. Teaching and Teacher Education, 26(8), 1641-1651.

Henze, I., van Driel, J.H., \& Verloop, N. (2008). Development of experienced science teachers' pedagogical content knowledge of models of the solar system and the universe. International Journal of Science Education, 30(10), 1321-1342.

Jenset, I.S., Klette, K., \& Hammerness, K. (2018). Grounding teacher education in practice around the world: An examination of teacher education coursework in teacher education programs in Finland, Norway, and the United States. Journal of Teacher Education, 69(2), 184-197.

Jones, M., \& Ryan, J. (Eds.). (2014). Successful teacher education: Partnerships, reflective practice and the place of technology. New York: Springer.

Kasapoğlu, K. (2015). A review of studies on school experience and practice teaching in Turkey. Hacettepe University Journal of Education, 30(1), 147-162.

König, J., \& Rothland, M. (2012). Motivations for choosing teaching as a career: Effects on general pedagogical knowledge during initial teacher education. Asia-Pacific Journal of Teacher Education, 40(3), 289-315.

Korthagen, F.A.J. (2000). Teacher educators, from neglected group to spearheads in the development of education. In G. Willems, J. Stakenborg, \& W. Veugelers (Eds.), Trends in Dutch teacher education (pp. 36-49). Garant, Leuvan-Apeldorn.

Krainer, K. (2008). Researchers and their roles in teacher education. Journal of Mathematics Teacher Education, 11(4), 253-257.

Krippendorff, K. (2004). Content analysis: An introduction to its methodology. Thousand Oaks, CA: Sage.

Kruger, T., Davies, A., Eckersley, B., Newell, F., \& Cherednichenko, B. (2009). Effective and sustainable university-school partnerships. Beyond determined efforts of inspired individuals. Canberra: Teaching Australia. Electronic version Retrieved from http://hdl.voced.edu.au/10707/144200 
Lannin, J.K., Webb, M., Chval, K., Arbaugh, F., Hicks, S., Taylor, C., \& Bruton, R. (2013). The development of beginning mathematics teacher pedagogical content knowledge. Journal of Mathematics Teacher Education, 16, 403-426.

Lave, J., \& Wenger. E. (1991). Situated learning: Legitimate peripheral participation. Cambridge, U.K.: Cambridge University.

Loughran, J. (2006). Developing a pedagogy of teacher education: Understanding teaching and learning about teaching. New York: Routledge.

Loughran, J., Mulhall, P., \& Berry, A. (2008). Exploring pedagogical content knowledge in science teacher education. International Journal of Science Education, 30(10), 1301-1320.

Lunenberg, M., \& Hamilton, M-L. (2008). Threading a golden chain: An attempt to find our identities as teacher educators. Teacher Education Quarterly, 35(1), 185-205.

Lunenberg, M., Korthhagen, F., \& Zwart, R. (2011). Self-study research and the development of teacher educators' professional identities. European Educational Research Journal, 10(3), 407-420.

MacPhail, A., Ulvik, M, Guberman, A., Czerniawski, G., Oolbekkink-Marchand, H., \& Bain, Y. (2019). The professional development of higher education-based teacher educators: Needs and realities. Professional Development in Education, 45(5), 848-861.

Molseed, T.R. (2000). Redesigning pre-service teacher practices through staff development: Serendipitous growth for classroom teachers. Education, 120(3), 474-478.

Moradkhani, S., Akbari, R., Ghafar Samar, R., \& Kiany, G.R. (2013). English language teacher educators' pedagogical knowledge base: The macro and micro categories. Australian Journal of Teacher Education, 38(10). http://dx.doi.org/10.14221/ajte.2013v38n10.7

Murray, J., Swennen, A., \& Shagrir, L. (2009). Understanding teacher educators' work and identities. In A. Swennen \& M. van der Klink (Eds.), Becoming a Teacher Educator. Dordrecht: Springer.

Niemi, H. (2016). Academic and practical: Research-based teacher education in Finland. In B. Moon (Ed.), Do universities have a role in the education and training of teachers? An international analysis of policy and practice (pp. 19-33). Cambridge, U.K.: Cambridge University.

Niemi, H., Jakku-Sihvonen, R. (2006). Research-based teacher education. In R. Jakku-Sihvonen \& H. Niemi (Eds.), Research based teacher education in Finland: Reflections by Finnish teacher educators (pp. 31-47). Turku: Finnish Educational Research Association.

Norton, A., \& Wilkins, J.L.M. (2012). The splitting group. Journal for Research in Mathematics Education, 43(5), 557-583.

Özcan, M. (2013). Okulda Üniversite: Türkiye'de öğretmen eğitimini yeniden yapılandırmak için bir model önerisi. [University within School: A new model to re-structure teacher education in Turkey]. Ankara: TÜSİAD.

Patton, M.Q. (2002). Qualitative research \& evaluation methods. Thousand Oaks, California: Sage.

Ping, C., Schellings, G., \& Beijaard, D. (2018). Teacher educators' professional learning: A literature review. Teaching and Teacher Education, 75, 93-104.

Ping, C., Schellings, G., Beijaard, D., \& Ye, J. (2020) Teacher educators' professional learning: Perceptions of Dutch and Chinese teacher educators. Asia-Pacific Journal of Teacher Education. doi: 10.1080/1359866X.2020.1725808

Potari, D., Sakonidis, H., Chatzigoula, R., \& Manaridis, A. (2010). Teachers' and researchers' collaboration in analyzing mathematics teaching: A context for professional reflection and development. Journal of Mathematics Teacher Education, 13(6), 473-485.

Sandholtz, J.H. (2002). Inservice training or professional development: Contrasting opportunities in a school/university partnership. Teaching and Teacher Education, 18(7), 815-830.

Schön, D. (1983) The reflective practitioner: How professionals think in action. New York: Basic Books.

Sharplin, E. (2011). How to be an English teacher and an English teacher educator: Spanning the boundaries between sites of learning. English in Australia, 46(2), 67-76.

Sherin, M.G., Jacobs, V.R., \& Philipp, R.A. (Eds.). (2011). Mathematics teacher noticing: Seeing through teachers' eyes. New York: Routledge. 
Shulman, L.S. (1986). Those who understand: Knowledge growth in teaching. Educational Researcher, 15(2), 4-14.

Smith, K. (2005). Teacher educators' expertise: What do novice teachers and teacher educators say?

Teaching and Teacher Education, 21(2), 177-192.

Steffe, L.P., \& Olive, J. (2010). Children's fractional knowledge. New York: Springer.

Stemler, S. (2001). An overview of content analysis. Practical assessment, research \& evaluation, 7(17), 137-146.

Swennen, A., Jones, K., \& Volman, M. (2010). Teacher Educators: Their identities, sub-identities and implications for professional development. Journal for Professional Development in Education, $36(1 \& 2), 131-148$.

Torbeyns, J., Verbruggen, S., \& Depaepe, F (2020). Pedagogical content knowledge in preservice preschool teachers and its association with opportunities to learn during teacher training. ZDM Mathematics Education, 52, 269-280.

Tunç-Pekkan, Z. (2008). Modeling grade eight students' construction of fraction multiplying schemes and algebraic operations. [Unpublished Doctoral Thesis]. University of Georgia. Athens, GA. USA.

Tunç-Pekkan, Z. (2015). An analysis of elementary school children's fractional knowledge depicted with circle, rectangle, and number line representations. Educational Studies in Mathematics, 89(3), 419-441.

Turnuklu, E.B., \& Yesildere, S. (2007). The pedagogical content knowledge in mathematics: Pre-service primary mathematics teachers' perspectives in Turkey. Issues in the Undergraduate Mathematics Preparation of School Teachers, IUMPST: The Journal, 1, 1-13.

Tzur, R. (1999). An integrated study of children's construction of improper fractions and the teacher's role in promoting that learning. Journal for Research in Mathematics Education, 30(4), 390-416.

van der Klink, M., Kools, Q., Avissar, G., White, S., \& Takata, S. (2017). Professional development of teacher educators: What do they do? Findings from an explorative international study. Professional Development in Education, 43(2), 163-178.

Vanassche, E., \& Kelchtermans, G. (2016). Facilitating self-study of teacher education practices: Toward a pedagogy of teacher educator professional development. Professional Development in Education, 42(1), 100-122.

Wilhelm, A.G. (2014). Mathematics teachers' enactment of cognitively demanding tasks: Investigating links to teachers' knowledge and conceptions. Journal for Research in Mathematics Education, 45(5), 636-674.

Wilson, N.S. (2008). Teachers expanding pedagogical content knowledge: Learning about formative assessment together. Journal of In-Service Education, 34(3), 283-298.

Yin, R. (1994). Case study research: Design and methods (2nd ed.). Thousand Oaks, CA: Sage.

Yogev, S., \& Yogev, A. (2006). Teacher educators as researchers: A profile of research in Israeli teacher colleges versus university departments of education. Teaching and Teacher Education, 22(1), 32 41.

Zeichner, K. (1999). The new scholarship in teacher education. Educational Researcher, 28(9), 4-15. 